\title{
強風下における建築物の耐震性に関する研究 STUDY ON SEISMIC PERFORMANCE OF BUILDINGS UNDER THE EFFECT OF HIGH WIND
}

\author{
平石久廣*，吉益幸寛**，露木裕史**，喜々津仁密*** \\ Hisahiro HIRAISHI, Yukihiro YOSHIMASU, Hiroshi TSUYUKI \\ and Hitomitsu KIKITSU
}

\begin{abstract}
This paper studies seismic performance of reinforced concrete buildings under the effect of high wind. Three types of structures of earthquake-resistant construction, damper construction and base isolation construction, two types of seismic force of moderate earthquake and severe earthquake, and three different levels of wind load are investigated.

Following items were found through this study; in the case that buildings form plastic hinge mechanism, they deform into one-way and show poor energy consumption, so, their deformation remarkably increases, and this increase is controlled if the damper with the same strength as the wind load is installed in the building.
\end{abstract}

Keywords : Reinforced concrete buildings, Earthquake response analysis, Ductility factor, Base shear coefficient, Wind load 鉄筋コンクリート造，地震応答解析，塑性率，ベースシア係数，風荷重

\section{1. はじめに}

現行の建築基準法では地震力と風圧力に対する構造安全性の検証 はそれぞれ独立に行われており，風圧力の作用時に地震力を受ける ことを想定した安全性の確認はされていない。このことから，以下 の観点を踏まえた強風下での鉄筋コンクリート造建築物の耐震性に 関する知見は十分でないのが現状である。

1) 通常の設計で想定する「稀に発生する暴風」以下の風速レベル の強風は発生頻度が高くなる。

2) 強風は瞬間的に作用する地震よりも長く作用する。

そこで本論文では, 強風下で中地震又は大地震が発生し, 地震力 と風圧力を同時に受けた場合の定性的な応答性状について検討した。 具体的には，建築基準法に定める基準風速未満の平均風速を想定し た風荷重下において,「稀に発生寸る地震 (中地震) 」及び「極めて稀 に発生する地震 (大地震) 」を受ける場合について単純化した建築物 モデルの応答解析を行い, その応答性状の定性的な傾向について考 察を行った。構造特性として耐震モデル，制振モデル及び免震モデ ルを解析の対象とし, 解析結果を踏まえて風荷重による応答増大の 防止についても検討を行った。

なお，強風下で地震動が発生した事例としては，2009年 8 月 11 日午前 5 時 7 分に静岡県御前崎沖の駿河湾で発生した地震 (マグニチ ユード 6.5) が挙げられる。この地震では御前崎市で震度 6 弱を記録 しているが, ちょうど同日には台風 9 号が関東・東海地方に接近し, 地震発生時に平均風速 $8 \mathrm{~m} / \mathrm{s}$, 瞬間風速 $13 \mathrm{~m} / \mathrm{s}$ 程度を観測している ${ }^{1)}$ 。 一般に大型の台風が接近中の強風下で中地震又は大地震が発生する といった事象は極めて稀であるが，上記のような事例を念頭に置い て建築物の構造特性に応じた耐震性に対する風荷重の影響を把握す
ることは, よりグレードの高い構造性能確保の観点からも意義があ るものと考える。

\section{2. 解析概要}

本研究では，建築物を一自由度系に置き換えて検討を行った。建 築物高さ，ベースシア係数及び風速をパラメータとし，一自由度系 のモデルに対して風荷重を静的な荷重として加えている状態で，中 地震波と大地震波の異なる 3 波ずつを入力し，風荷重と地震力を同 時に受けた場合の地震応答解析を行う。解析は，建築構造物の振動 解析プログラム RESP-F3T（株式会社 構造計画研究所）を用いて行 った。解析の流れを図 1 に示寸。

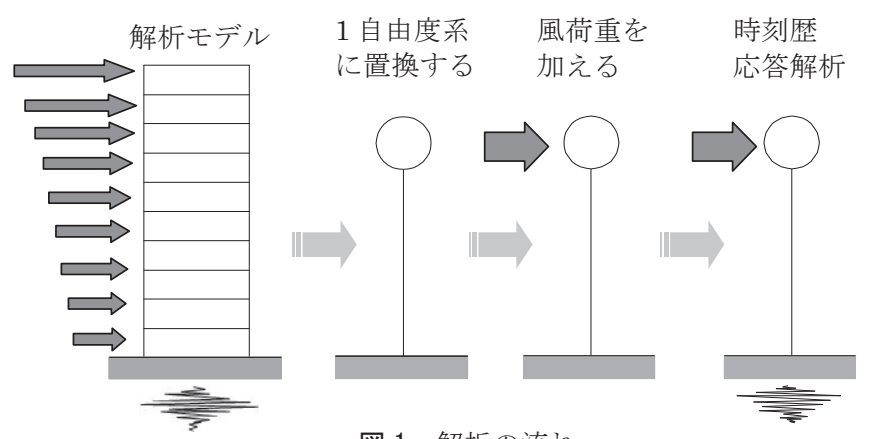

図 1 解析の流れ

\section{1 解析対象建築物の設定}

解析対象の鉄筋コンクリート造建築物の概要を以下に示す。なお, 構造特性は第 3 節に記述する。
* 明治大学理丁学部建築学科 教授. 丁博 (独立行政法人建築研究所 客員研究員)

** 明治大学大学院理工学研究科 博士前期課程

*** 国土交通省国土技術政策総合研究所 主任研究官·博士 (環境学)
Prof., Dept. of Architecture, School of Science and Technology, Meiji Univ., Dr. Eng.

(Visiting Research Fellow, Building Research Institute)

Graduate School of Science and Technology, Meiji Univ.

Senior Researcher, National Institute for Land and Infrastructure Management, Ph. D. 
1) 階数は 10 階, 20 階, 30 階建の 3 ケースとし, 階高を $3.5 \mathrm{~m}$ と して建築物高さをそれぞれ $35 \mathrm{~m} ， 70 \mathrm{~m} ， 105 \mathrm{~m}$ とした。

2）基礎は固定とした。

3) 平面図は図 2 のように, 梁間方向 1 スパン (スパン長さ $12 \mathrm{~m}$ ), 桁行方向 6 スパン（スパン長さ $6 \mathrm{~m}$ ) とし, 単位面積重量 $\mathrm{w}$ は $11.76 \mathrm{kN} / \mathrm{m}^{2}$ とした。

4) 等価質量, 代表高さについては, 主たる応答が地震動によるも のと仮定し, その場合の標準的な建築物の有効質量比の值とし て 0.81 ，代表高さの標準的な值として 0.73 を設定した。

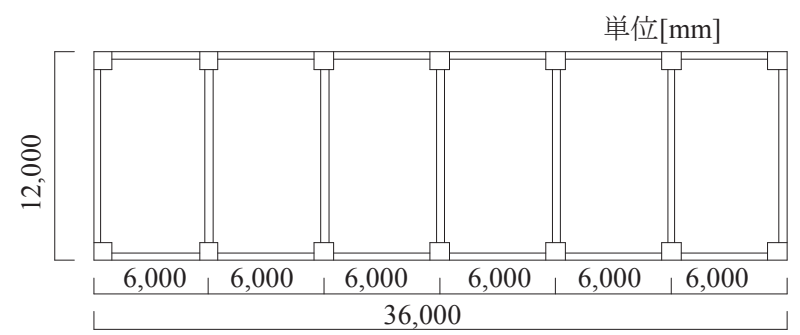

図 2 解析建築物平面図

\section{2 地震波の設定}

地震波は, 表層地盤の影響を考慮した第二種地盤の加速度応答ス ペクトルを元に作成した告示波の 3 波を用いた。地震波の加速度応 答スペクトルを図 3 に示寸。また, 中地震波の時刻歴波形を図 4.1 に, 大地震波の時刻歴波形を図 4.2 にそれぞれ示す。

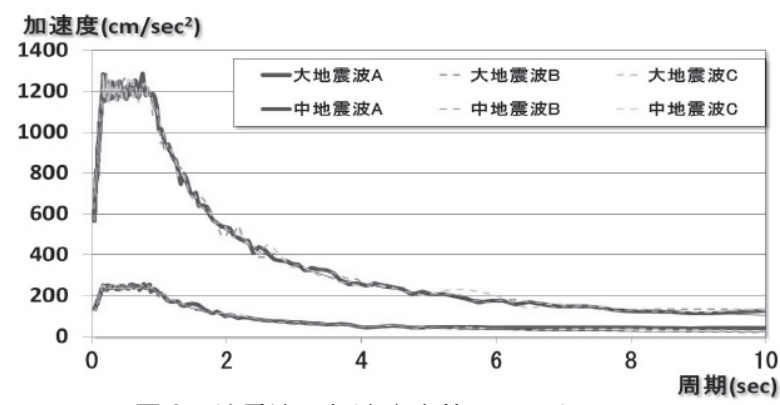

図 3 地震波の加速度応答スペクトル



図 4.1 中地震波の時刻歷波形

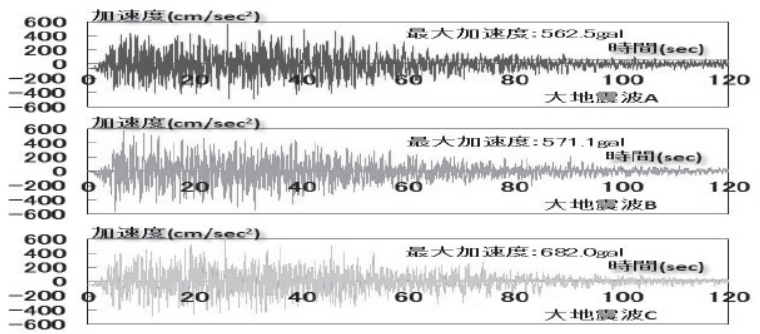

図 4.2 大地震波の時刻歷波形

\section{3 平均風荷重の算定}

一般に，地震荷重と風荷重各々の変動成分の相関性は低いと考え られる。本研究では文献 2)に定める風荷重作用時の地震荷重評価の 考え方に準じて，風荷重は平均成分のみを考慮した。また，梁間方 向に平行な風向を想定し，地表面粗度区分 II の地点での風向方向の 風荷重を対象にする。

文献 3), 4)より, 平均速度圧 $\bar{q}$ は式(2.1)によって得られる。

$\bar{q}=0.6 E_{r}{ }^{2} V^{2}$

$V$ 地表面粗度区分 II での地上 $10 \mathrm{~m}$ の平均風速 $(\mathrm{m} / \mathrm{s})$

$E_{r} \quad$ 平均風速の高さ方向の分布を表す係数

以下では，図 5 のように建築物の各階に加わる風荷重を算定し， それらの合計が建築物全体に加わると仮定して解析を行った。した がって, 一質点モデルが受ける平均風荷重 $P$ は, 式(2.1)を用いて式 (2.2)で与えられる。

$$
P=0.6 E_{r}{ }^{2} V^{2} \sum_{i=1}^{n} C_{f i} \cdot A_{i}
$$

$C_{f i} \quad i$ 階の高さにおける風力係数

$A_{i} \quad i$ 階が負担する風圧力の見付け面積

$n$ 階数
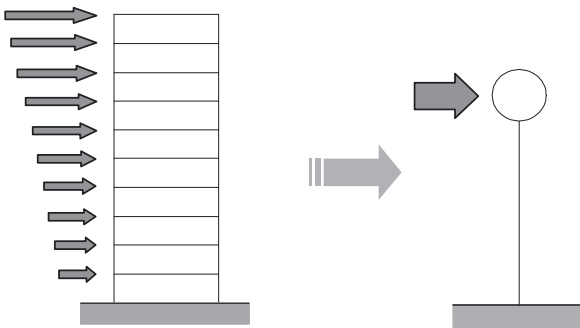

図 5 風荷重の算定

風速レベルに対する応答変化の定性的な傾向及び応答増加時の履 歴性状を把握するため，応答に有意な影響が認められる範囲まで平 均風速 $V$ の数值を変化させて解析を行った。以下では，V=0（風な し) $, 15,20,25 \mathrm{~m} / \mathrm{s}$ の場合の結果を掲げる。表 1 に平均風速 $V$ に対 応した平均風荷重 $P$ 及び建築物重量 $W$ に対する風荷重の割合 $P / W$ を示す。階数が増加するほど割合 $P / W$ が増加している。

表 1 階数と風速に応じた平均風荷重

\begin{tabular}{|c|c|c|c|}
\hline 階数 & 風速 $V(\mathrm{~m} / \mathrm{s})$ & 平均風荷重 $P($ ton $)$ & $P / W$ \\
\hline \multirow{3}{*}{10} & 15 & 24.83 & 0.0059 \\
\cline { 2 - 4 } & 20 & 44.14 & 0.0105 \\
\cline { 2 - 4 } & 25 & 68.97 & 0.0164 \\
\hline \multirow{3}{*}{20} & 15 & 62.02 & 0.0148 \\
\cline { 2 - 4 } & 20 & 110.25 & 0.0263 \\
\cline { 2 - 4 } & 25 & 172.27 & 0.0410 \\
\hline \multirow{3}{*}{30} & 15 & 105.53 & 0.0251 \\
\cline { 2 - 4 } & 20 & 187.61 & 0.0447 \\
\cline { 2 - 4 } & 25 & 293.13 & 0.0698 \\
\hline
\end{tabular}

\section{3. 解析対象建築物の構造特性の設定}

以下に, 解析対象建築物である「耐震モデル」,「制振モデル」及 び「免震モデル」の復元力特性をそれぞれ示す。 


\section{1 耐震モデル}

1) 10，20，30 階建の各建築物に対して，文献 5)より塑性率を 2 とした時の必要ベースシア係数 $\mathrm{C}_{\mathrm{B}}$ を定めた。また, 既存建築 物に近いベースシア係数を有する場合についても検討を行っ た。

10 階建 $\cdots \mathrm{C}_{\mathrm{B}}=0.25,0.35 *$

20 階建 $\cdots \mathrm{C}_{\mathrm{B}}=0.15,0.25 *$

30 階建 $\cdots \cdot \mathrm{C}_{\mathrm{B}}=0.10,0.20^{*}\left(*\right.$ : 既存建築物の $\mathrm{C}_{\mathrm{B}}$ )

以下では, 限界耐力計算でベースシア係数を設定した耐震モデ ルを「限耐耐震モデル」, 既存建築物に近いベースシア係数を 設定した耐震モデルを「既存耐震モデル」と称する。

2) 復元力特性は，曲げひび割れおよび曲げ降伏によって剛性が 変化するトリリニアとする。図 6 に仮定した復元力特性のス ケルトンカーブを示す。降伏剛性低下率 $\alpha_{y}$ を 0.3 とし, ひび 割れ耐力は降伏耐力の $1 / 3$ とした。トリリニアカーブの第 3 勾 配は初期剛性の $1 / 1000$ とした。降伏变形角は 1/120 とした。

3) 履歴モデルは修正武田モデルを用いた。粘性減衰は瞬間剛性 比例型で, 減衰定数は弾性 1 次モードに対して $3 \%$ とした。

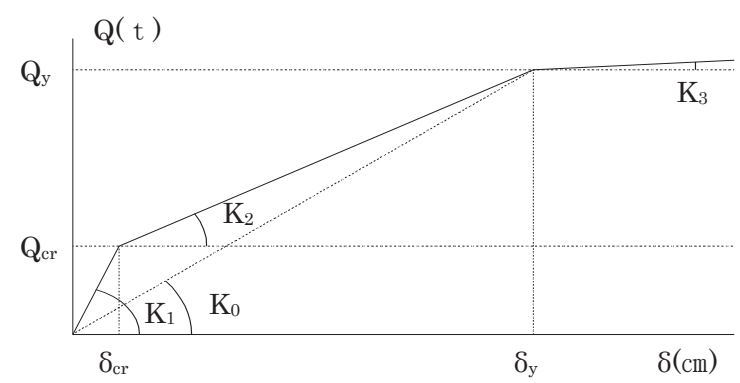

図 6 変位とせん断力の関係

3.2 制振モデル

1) 建築物とダンパーの耐力を併せた耐力が，10，20，30 階建の限 耐耐震モデルの保有耐力時ベースシア係数 $\mathrm{C}_{\mathrm{B}}$ と同じになるよ うに仮定し，10 階建， 20 階建，30 階建でそれぞれ $\mathrm{C}_{\mathrm{B}}=0.25$, 0.15，0.10とした。また，各々の階数の建築物とダンパーの耐 力の割合は $8: 2$ とした。

2)建築物躯体の剛性, 履歴モデル, 粘性減衰及び減衰定数は耐震 モデルと同様に設定した。ダンパーの剛性は，曲げ降伏によっ て剛性が変化するバイリニアとし，ダンパーの降伏は文献 6) を参考に，建築物高さの $1 / 750$ で発生する。降伏後の剛性は初 期剛性の 1/1000 とした。履歴モデルは完全弾塑性モデルを用い た。粘性減衰は瞬間剛性比例型で, 減衰定数は $3 \%$ とした。図 7 に復元力特性のスケルトンカーブを示す。

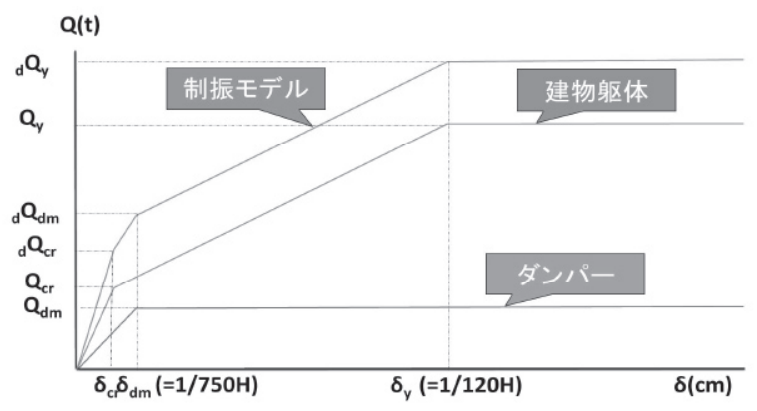

図 7 制振モデルのスケルトンカーブ

\section{3 免震モデル}

既存耐震モデルとの比較を目的とし，既存建築物に近い強度を有 する免震モデルについて風荷重作用時の耐震性状を検討した。この 既存建築物を想定した建築物の強度，復元力特性の設定方法は文献 6)より以下のように定めた。

1) 積層ゴム

積層ゴムの復元力特性は弾性型とした。固有周期を $T e=4(\mathrm{~s})$ とし て仮定し，式(3.1)に $M u$ を代入することにより $K_{f}$ を決定した。

$$
\begin{gathered}
T_{e}=2 \pi \sqrt{\frac{M_{u}}{K_{f}}} \\
K_{f} \quad \text { 積層ゴムの水平ばね剛性 } \quad M_{u} \text { 等価質量 }
\end{gathered}
$$

2) 鋼材ダンパー（弾塑性ダンパー）

鋼材ダンパーの復元力特性はバイリニアとした。鋼材ダンパーの 場合，ダンパーが吸収する地震エネルギーを表した式は，式(3.2)の ように表せる。

$$
\begin{aligned}
E_{d}= & 4 Q_{d y}(\mu-1) u_{d y} \\
E_{d} & \text { ダンパーが吸収する地震エネルギー } \mu \text { 塑性率 } \\
Q_{d y} & \text { 必要ダンパー耐力 } \quad u_{d y} \quad \text { 降伏変位 }
\end{aligned}
$$

減衰定数は履歴面積の 8 割を有効とすると式(3.3)のように表せる。

$$
h_{e q}=0.8 \times \frac{E_{d}}{2 \pi K_{f} u_{\max }^{2}}
$$

式(3.3)を変形して必要ダンパー耐力は式(3.4)で求められる。ここ では $h_{e q}=30 \%, u_{y}=3 \mathrm{~cm}, u_{\max }=45 \mathrm{~cm}$ とした。

$$
\begin{aligned}
& Q_{d y}=\frac{\pi h_{e q} K_{f} u_{\max }^{2}}{1.6\left(u_{\max }-u_{d y}\right)} \\
& Q_{d y} \quad \text { 必要ダンパー耐力 } \quad u_{\max } \text { 最大変位 } \\
& h_{e q} \text { 等価減衰定数 } u_{y} \text { 降伏変位 }
\end{aligned}
$$

3）免震構造の復元力特性

図 8 のように積層ゴムと鋼材ダンパー（弾塑性ダンパー）の復元 力特性を足し合わせて考える。履歴モデルはノーマルモデルを用い た。粘性減衰は初期剛性比例型で, 考慮するのは履歴減衰のみとし た。
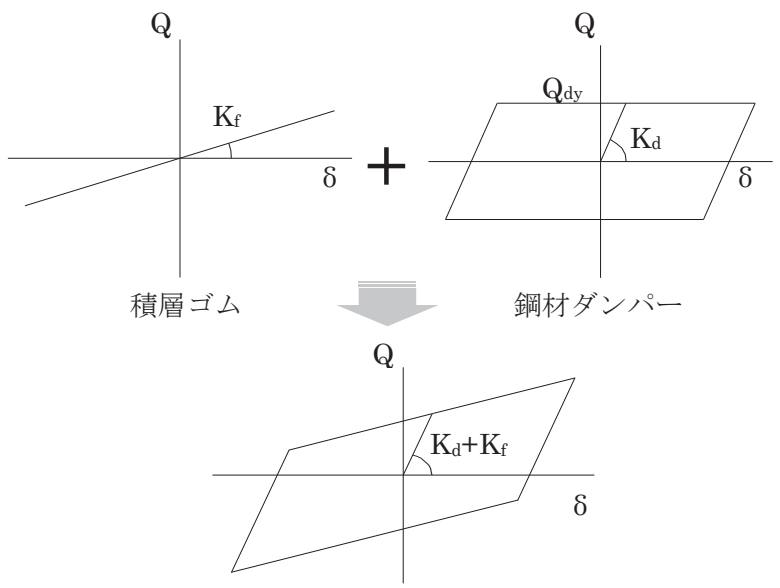

図 8 弾塑性ダンパー付き免震構造の履歴モデル 


\section{4. 解析結果}

中地震動及び大地震動のそれぞれ各 3 波のうち $\mathrm{A}$ 波の場合につい て, 各モデルの応答解析結果を以下に掲げる。図 9 , 図 10 が限耐耐 震モデル，図 11 ，図 12 が既存耐震モデル，図 18 ，図 19 が制振モデ ル, 図 20, 図 21 が免震モデルの応答結果である。なお, 図中の点 線は塑性率 2，実線は塑性率 3 をそれぞれ示す。

\section{1 耐震モデルの結果及びその検討}

中地震動時の場合, 限耐耐震モデルでは階数が多くなるにつれて 応答の増大傾向が見られるが，降伏には至っていない。一方の既存 耐震モデルでは，階数が多くなっても応答の増大傾向はあまり認め られない。次に大地震動時の場合, 限耐耐震モデルでは建築物に風 荷重が作用することによって変形の片ぶれが生じている。このため エネルギー吸収の少ない履歴ループとなる。また, 図 13 のように塑 性率が大きくなっても, 片ぶれのため繰り返し時の等価剛性はさほ ぞ小さくならない。結果として, 繰り返しとともに応答が増大し大 きな変形を生じている。

図14＼cjkstart図 17 に, 中地 震動時及び大地震動時に おける限耐耐震モデルと 既存耐震モデルの各風速 の風荷重下での最大建物 変形角を示す。ここで最 大建物変形角は, 各 3 波

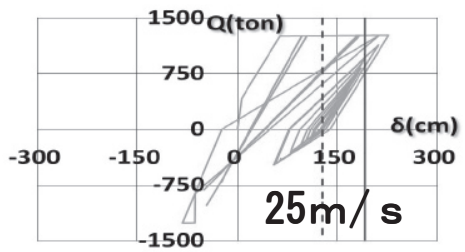

図 13 限耐耐震 30 階モデル (大地震)



(a) 10 階

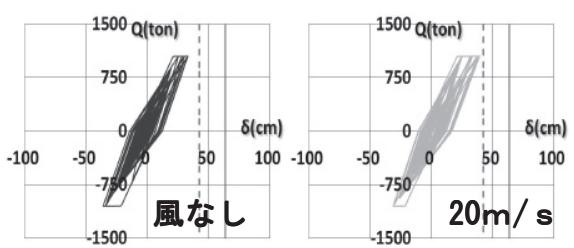

(a) 10 階

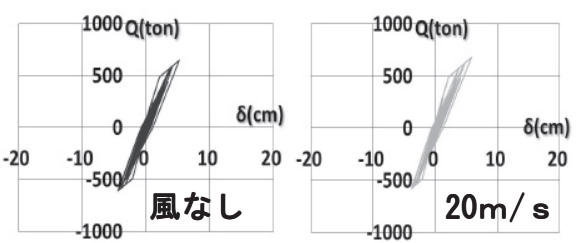

(a) 10 階

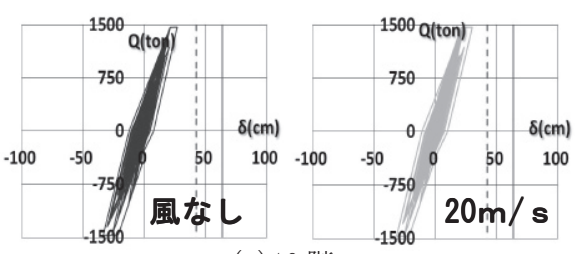

(a) 10 階

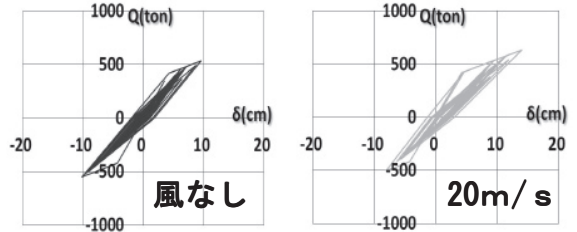

(b) 20 階

図 9 限耐耐震モデル (中地震)

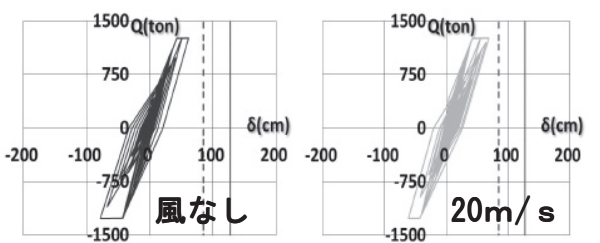

(b) 20 階

図 10 限耐耐震モデル (大地震)
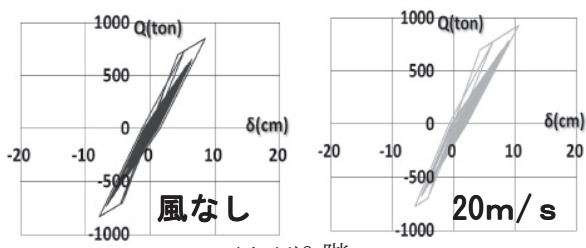

(b) 20 階

図 11 既存耐震モデル (中地震)
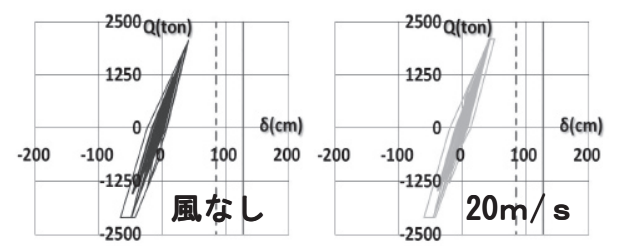

(b) 20 階

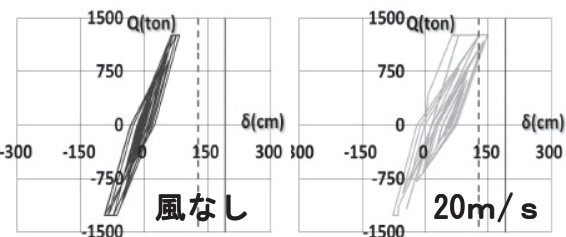

(c) 30 階

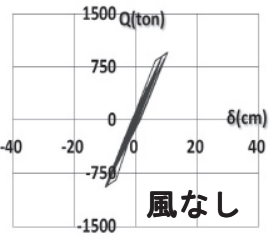

(c) 30 階

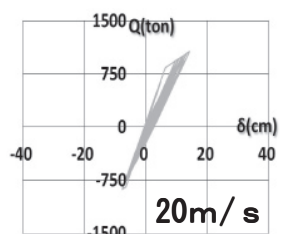

$20 \mathrm{~m} / \mathrm{s}$

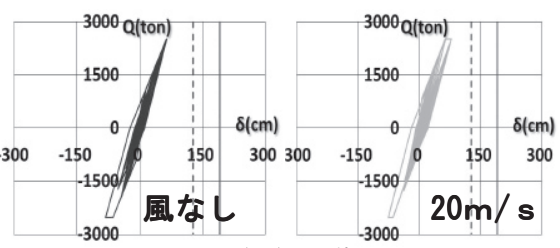

(c) 30 階

図 12 既存耐震モデル (大地震) 


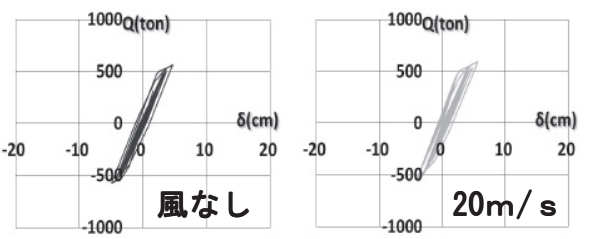

(a) 10 階

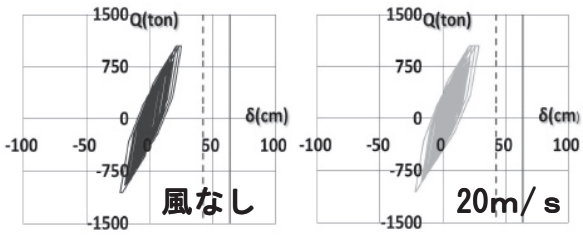

(a) 10 階
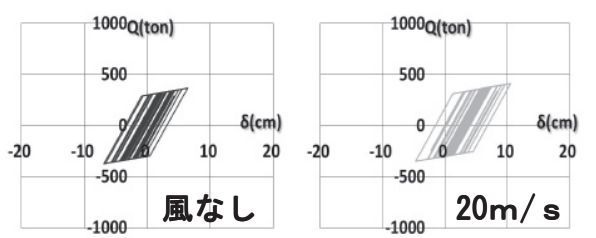

(a) 10 階



(a) 10 階

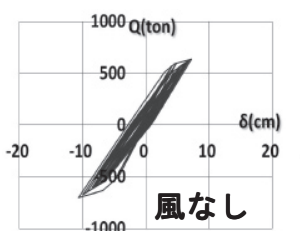

(b) 20 階

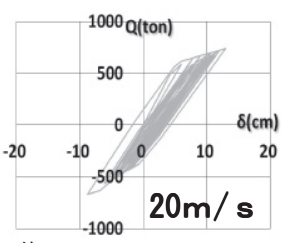

制振モデル (中地震)

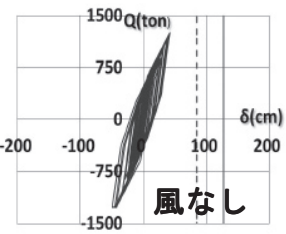

(b) 20 階

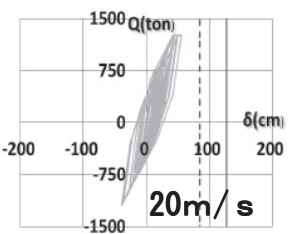

$20 \mathrm{~m} / \mathrm{s}$

図 19 制振モデル (大地震)
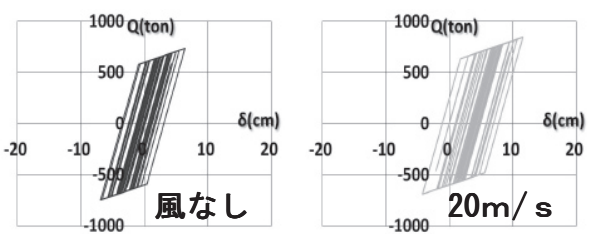

(b) 20 階

図 20 免震モデル (中地震)

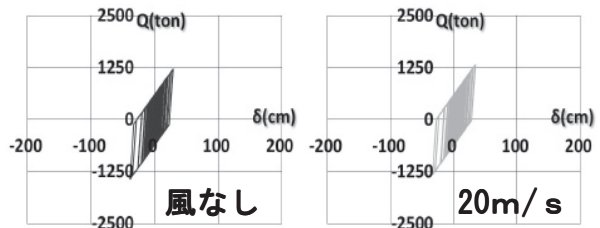

(b) 20 階

図 21 免震モデル (大地震)

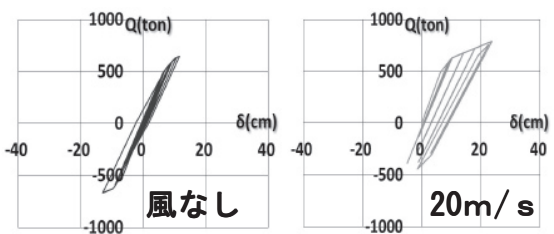

(c) 30 階

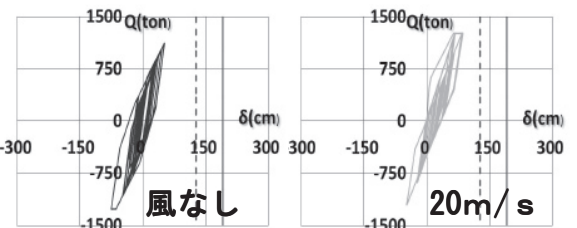

(c) 30 階

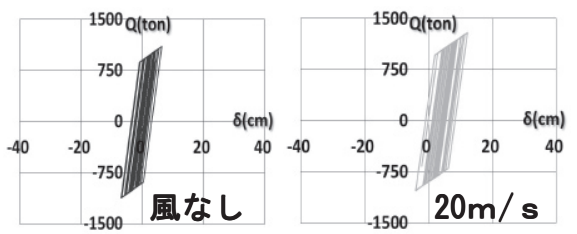

(c) 30 階

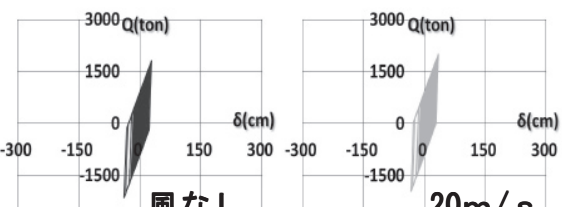

風なし

(c) 30 階

\section{2 制振モデルの結果及びその検討}

制振モデルでは中地震動時の場合, 想定する階数が多くなるにつ れて応答の増大が顕著に見られるが，降伏には至っていない。大地 震動時の場合, 建築物に風荷重が作用することにより, 限耐耐震モ デルと同様に変形の片ぶれが生じている。しかし，限耐耐震モデル と比べて片ぶれしても紡錘型の履歴性状を有していることが分かる。 図 22 , 図 23 に, 中地震動時及び大地震動時における制振モデル の各風速の風荷重下での最大建物変形角を示寸。なお，ここで示寸 最大建物変形角は 4.1 節と同様の方法で得たものである。

図 14, 図 15 に示す限耐耐震モデルと比較すると, 大地震動時で 風荷重に対する応答増大の程度は小さい。これは, 制振モデルにお いては耐震モデルより履歴面積が大きく且つ片ぶれしても紡錘型の 履歴を描くことに起因していると考えられる。

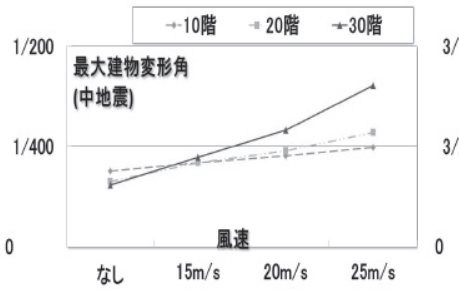

図 22 制振モデル (中地震)

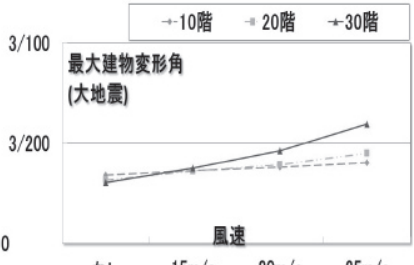

な $15 \mathrm{~m} / \mathrm{s} 20 \mathrm{~m} / \mathrm{s} \quad 25 \mathrm{~m} / \mathrm{s}$ 図 23 制振モデル (大地震)

\section{3 免震モデルの結果及びその検討}

免震モデルでは中地震動時及び大地震動時ともに, 建築物に風が 作用することにより変形の片ぶれが生じている。しかし，等価剛性 と履歴吸収エネルギーに大きな変化は認められない。

図 24, 図 25 に, 中地震動時及び大地震動時における免震モデル の各風速の風荷重下での最大層間変形角を示寸。ここで最大層間変 形角は, 各 3 波の地震波を作用させたときの最大応答変位の平均值 を免震層高さ $(45 \mathrm{~cm})$ で除した值である。

中地震動時では風荷重が作用すると応答に有意な影響が認められ, 図 16 に示寸既存耐震モデルの影響が小さい結果と対照的である。た だし, 20 階, 30 階モデルの変形の絶対值は免震モデルのほうが小さ い。また，大地震動時では風荷重の考慮の有無による影響は中地震 動時に比べて小さい。

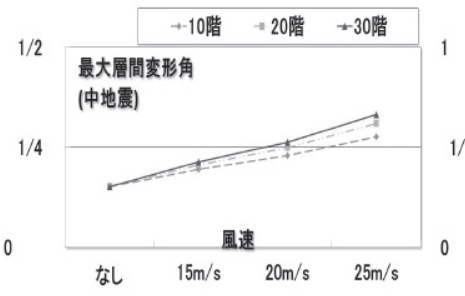

図 24 免震モデル (中地震)

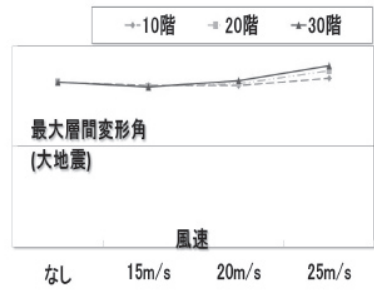

図 25 免震モデル (大地震) 


\section{5．風荷重による応答増大防止の検討}

本節では，前節で応答増大の程度が比較的大きかった限耐耐震モ デルと制振モデルの 30 階建を対象にして, 風荷重と同等の耐力を建 築物に付加することによる応答増大防止の可能性の検討を行った。

\section{1 解析対象モデルの設定}

解析対象モデルを図 26 に示す。ここで，作用する風荷重と同等の 耐力を耐震モデルの降伏耐力に付加したものを「風荷重付加耐震モ デル」, 作用する風荷重と同等の耐力を制振モデルのダンパーに付加 したものを「風荷重付加制振モデル」とそれぞれ称する。

解析については, 2.1 節の解析対象の設定で示した同様の解析を 風荷重付加耐震モデルと風荷重付加制振モデルの風荷重分の耐力を 付加した建築物について行った。

\section{2 解析結果}

大地震動の 3 波のうち $\mathrm{A}$ 波の場合について, 大地震動時における 各モデルの応答結果を図 27 , 図 28 にそれぞれ示す。なお, 図中の 点線は塑性率 2, 実線は塑性率 3 を示す。

風荷重付加制振モデルでは, 風荷重が作用しても地震動のみを受 ける場合の応答とほぼ同じである。この傾向については，10 階建， 20 階建の両モデルでも同様の結果が得られた。このことから，制振 モデルの場合については建築物に作用する風荷重分をダンパーに付 加することで風荷重による応答増加を防止できると言える。

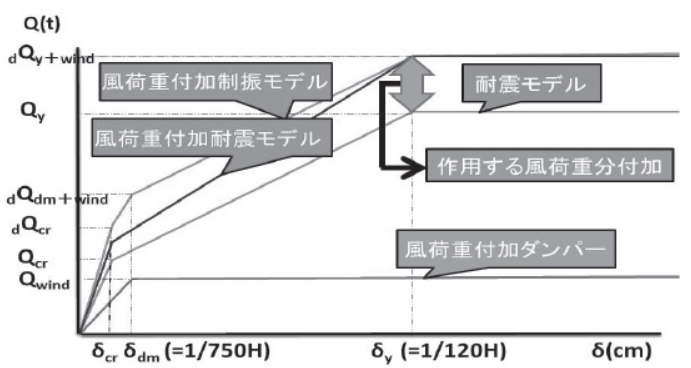

図 26 風荷重を付加した制振，耐震モデルのスケルトンカーブ

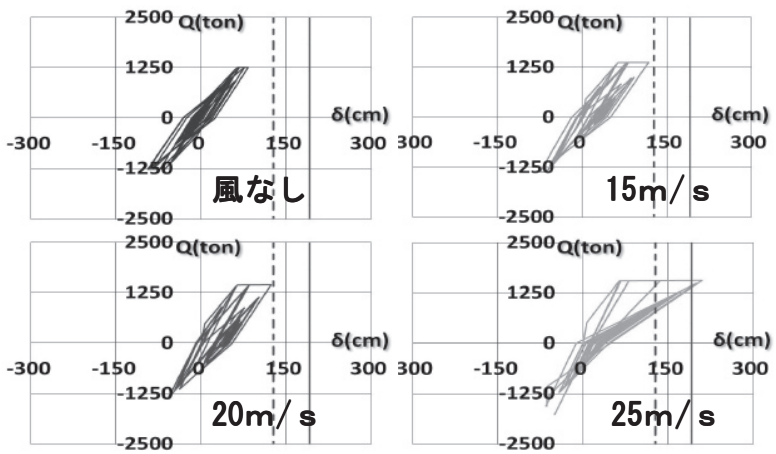

図 27 風荷重付加耐震 30 階モデル (大地震)

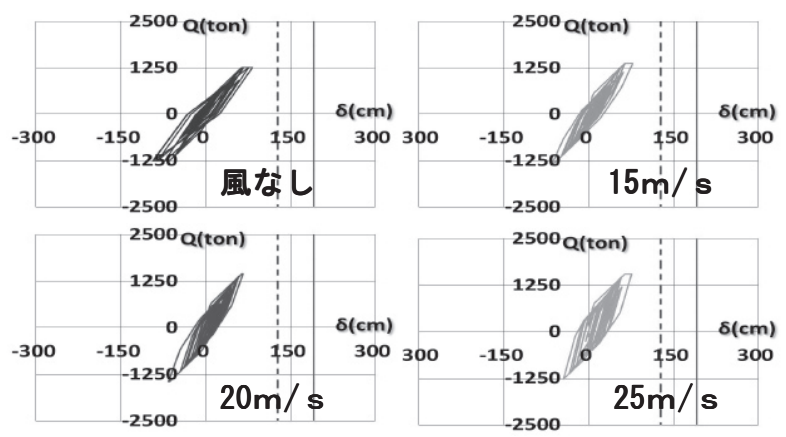

図 28 風荷重付加制振 30 階モデル (大地震)
一方，風荷重付加耐震モデルでは，風荷重の増加とともに応答も 増加する結果となった。これは，強度を増しても建築物に風荷重が 作用することにより変形の片ぶれが生じ，エネルギー吸収の少ない 履歴ループとなったことが要因だと考えられる。

\section{6. まとめ}

本研究では，強風下で地震が作用する場合の鉄筋コンクリート造 建築物の定性的な応答性状と応答増加時での履歴性状の把握を目的 とし，一自由度系の時刻歴応答解析を行った。また，解析結果を踏 まえ, 風荷重による応答増大防止の可能性についても検討を行った。 本研究によって得られた知見を以下に示す。なお，今後の課題と しては，風荷重の変動成分も考慮した場合の応答に対する影響の検 討，地震荷重と設計風速未満の風速に対応した風荷重との同時発生 の可能性の検討が挙げられる。

1）既存耐震モデル，大地震時の制振モデル及び免震モデルでは， 本研究で対象にした風速範囲での風荷重が応答に与える影響 は小さい。

2）限耐耐震モデルは，強風下において中地震動又は大地震動が 作用した場合，階数が多くなるにつれて著しい応答増大が見 られた。強風下で大地震動が作用する場合には，変形の片ぶ れが生じるために繰り返し時の等価剛性はそれほど小さくな らず，塑性化が進行しても繰り返しとともに応答が増大する 結果となっている。ただし，強風下で中地震動が作用しても 降伏には至っていない。

3) 限耐耐震モデルと同等のベースシア係数とした制振モデルは, 風と地震の同時作用によって変形の片ぶれが生じても紡鏵型 の履歴性状を有していることから，応答はあまり増大しない。

4) 固有周期を 4 秒と仮定した既存建築物に近い免震モデルは, 強 風下で大地震動が作用した場合, 既存耐震モデルに比べて応答 の増大が小さい。これは, 変形の片ぶれが生じても等価剛性と 履歴吸収エネルギーにおいて大きな変化がないことが大きな 要因である。

5）風荷重付加制振モデルは, 大地震動と風荷重が同時に作用した としても, 地震動のみを受ける場合の応答とほぼ同じになった。 したがって、建築物に作用する風荷重分をダンパーに付加する ことで風荷重による応答増加を防止できると言える。一方，風 荷重付加耐震モデルの応答は, 地震動のみを受ける場合よりも 大きな応答となった。

\section{参考文献}

1) 気象庁 気象統計情報 http://www.jma.go.jp/jma/menu/report.html，2011 年 6 月 1 日参照

2) 風力発電設備支持物構造設計指針・同解説，土木学会，2007.

3) 建築物の構造関係技術基準解説書編集委員会編集 : 2007 年版, 建築物 の構造関係技術基準解説書, 2007.8

4) 日本建築学会：建築物荷重指針・同解説 2004 年版, 2004.9

5) 平石久廣, 稲井栄一, 和田寿一, 福島徹 : 鉄筋コンクリート造建築物の 地震応答と耐震性能評価に関する研究, 日本建築学会構造系論文集, 第 613 号, pp. $105 \sim 112,2007.3$

6) 日本建築学会関東支部:免震・制振構造の設計一学びやすい構造設計一, 2007 